\title{
Full Molecular Screening of Colon Cancer in Patients Inherited Familial/Highly Germline BRCA1 and BRCA2 Mutations
}

\section{Dalal S. Alshaya}

Princess Nourah bint Abdulrahman University

\section{Tahani Mohamed Al-Hazani}

Prince Sattam bin Abdulaziz University

\section{Mashael Alhumaidi Alotaibi}

Jouf University

\section{Dalia Mostafa Domiaty}

Jeddah University: University of Jeddah

Alaa Ali AlQahtani

MNG-HA: Ministry of National Guard Health Affairs

\section{Fatima Abdullah AlQassim}

Regional Laboratory and Blood Bank

\section{Gadah Albasher}

King Saud University

Wedad Saeed Al-Qahtani ( $\nabla$ wed-mw@hotmail.com)

Naif Arab University for Security Sciences https://orcid.org/0000-0002-7347-9804

\section{Research Article}

Keywords: Molecular Screening, Colon Cancer, Familial Inherited, Germline Mutations, BRCA1\&2

Posted Date: October 25th, 2021

DOl: https://doi.org/10.21203/rs.3.rs-966714/v1

License: @ (i) This work is licensed under a Creative Commons Attribution 4.0 International License. Read Full License 


\section{Abstract}

Background: A significant body of research has presented evidence regarding an increasing number of cases of early colon cancer among young people. The present study aimed to assess the inherited germinal mutations in breast cancer 1 (BRCA1) and breast cancer 2 (BRCA2) coding areas in four consanguineous cases in generations of a single Saudi family.

Methods: The sample consisted of a single Saudi family of four generations in Riyadh, Saudi Arabia. The family has been diagnosed with colon cancer and inherited germline mutations in BRCA1 and BRCA2. DNA sequencing was used to examine the entire coding BRCA1 and BRCA2 sections. The colon samples were immunohistochemically and histologically analysed using BRCA1 and BRCA2 antibodies and H\&E Staining Kit (Hematoxylin and Eosin), respectively.

Results: A total of 21 scenarios at-risk consanguineous cases were mutations carriers of the $B R C A$ genes (2 $B R C A 2$ and $4 B R C A 1$ ), comprised of 3 affected consanguineous cases with malignant colon cancer. The $B R C A$ nucleotide sequencing revealed substantial mutation's cases in the BRCA1 genes (frameshift mutations situated within exon 11 and exon 2, where no such mutations were present in the BRCA2 genes). A novel replacement mutation within BRCA2 (exon 18) of $139 \mathrm{C}>\mathrm{A}$ was obtained with $(45.83 \%$ ) in females and $(31.26 \%)$ in males. Immunohistochemical staining showed positive staining for BRCA1 and BRCA2.

Conclusions: The major factor responsible for colon cancer incidences among the family is associated with the inherited mutations of the germline in BRCA2 and BRCA1 through repeated endogamy of consanguineous cases of the carriers of the mutation.

\section{Trial registration}

Retrospectively registered.

\section{Background}

Colon cancer is a heterogeneous disease with at least three distinct subtypes: colitis-associated, hereditary and sporadic colon cancer. Hereditary colon cancer accounts for roughly $10-15 \%$ of all colon cancers [1]. Breast cancer 1 (BRCA1) and breast cancer 2 (BRCA2) genes act as caretaker genes that maintain genome integrity and tumour suppressor's genes $[3,5]$. The rate of $B R C A 2$ and $B R C A 1$ gene mutations vary in different regions and countries $[2,4]$, and they account for $5-10 \%$ of colon and breast cancer [3]. The BRCA1 gene is found on chromosome 17, encompassing 24 exons encoding the protein of 1,863 various amino acids. However, the BRCAZs gene is found on chromosome 13 encompassing 27 exons encoding the protein of 3,418 amino acids [6]. More than 700 BRCA1's mutations and more than $600 B R C A 2$ 's mutations are reported in the coding regions [7]. Estimations indicated that several patients with $B R C A 2$ and $B R C A 1$ genes inherited mutations susceptible to 3 -fold increased risks of developing colon, breast, and pancreatic cancer [8, 15]. In addition, conventional histopathology, molecular analysis and immunohistochemistry provide enormous information regarding types of cancer [9-12]. The highly favourable methods for identifying sequences are heteroduplex analysis and single-strand conformation polymorphism analysis as they are sensitive and simple in detecting germinal mutations [12]. 
Patients with hereditary familial colon cancer have germline $B R C A 2$ and $B R C A 1$ mutations, in the form of adenomas colonic mucosa. During the process, patients obtain germline mutations within the BRCA2 and $B R C A 1$ genes [7, 8]. Consequently, the cellular mechanism associated with these inherited genes' changes the tissues of both breast and colon tumorigenesis $[4,14,15]$.

Although $B R C A 1 / 2$ have been studied extensively, Saudi data is still insufficient. This study aims to report the specific germinal mutations of $B R C A 2$ and $B R C A 1$, within the entire coding regions for highly/familial inherited mutations, to investigate the incidence of colon cancer in consanguineous cases of four generations in a Saudi Arabian family. The study aims to assess other related cofactors that increase colon cancer and other types of cancer among the consanguineous cases within the family.

\section{Methods}

\section{Ethics statement and human participants}

The current study obtained the approval of the Deanship of Scientific Research at Princess Norah Bint Abdulrahman University. This study was approved by the National Committee of Bioethics, King Abdulaziz City for Science and Technology, Kingdom of Saudi Arabia (Study number H-01-R059, IRB LOG number 200287). The written acquainted permissions have been obtained from the participants before obtaining their samples.

\section{Case selection and samples collection}

The study collected data of 24 consanguineous cases of affected carriers and patients from a single Saudi family (of four generations) in Riyadh, Saudi Arabia. Three biopsy samples were obtained from 24 relatives affected by malignant colon cancer in August 2020 at the King Fahad Medical City in Riyadh, Saudi Arabia.

Table 1 summarised the benchmarks of demographic profiles of all the consanguineous cases. Table 2 shows the tumour, node, metastasis (TNM) classifications of malignant colon cancer of the participating consanguineous cases of the affected patients. 
Table 1

Benchmark demographic profiles showing clinical characteristics of the participating consanguineous cases in four generations and consanguineous cases of mutated couples

\begin{tabular}{|c|c|c|c|c|c|c|c|c|}
\hline $\begin{array}{l}\text { Cases } \\
\#\end{array}$ & $\begin{array}{l}\text { Age at } \\
\text { diagnosis } \\
\text { (years) }\end{array}$ & Gender & $\begin{array}{l}\text { Family } \\
\text { history } \\
\text { with other } \\
\text { types of } \\
\text { cancer }\end{array}$ & $\begin{array}{l}\text { Diagnosed } \\
\text { with colon } \\
\text { cancer }\end{array}$ & $\begin{array}{l}\text { BRCA1 \& } \\
\text { BRCA2 } \\
\text { mutations }\end{array}$ & $\begin{array}{l}\text { Smoking } \\
\text { history }\end{array}$ & $\begin{array}{l}\text { Chronic } \\
\text { colitis } \\
\text { history }\end{array}$ & $\begin{array}{l}\text { Obesity } \\
(\mathrm{BMl} \geq \\
25 \mathrm{~kg})\end{array}$ \\
\hline 1 & 79 & M & unknown & YES & YES & - & - & - \\
\hline 2 & 76 & $\mathrm{~F}$ & - & - & YES & - & - & YES \\
\hline 3 & 59 & $M$ & $\begin{array}{l}\text { YES - } \\
\text { breast }\end{array}$ & - & YES & YES & YES & - \\
\hline 4 & 55 & $\mathrm{~F}$ & $\begin{array}{l}\text { YES - } \\
\text { pancreatic } \\
\& \text { breast }\end{array}$ & - & YES & - & - & YES \\
\hline 5 & 55 & $M$ & $\begin{array}{l}\text { YES - } \\
\text { breast }\end{array}$ & - & YES & - & - & - \\
\hline 6 & 53 & $\mathrm{~F}$ & $\begin{array}{l}\text { YES - } \\
\text { breast }\end{array}$ & - & YES & - & YES & YES \\
\hline 7 & 51 & $M$ & $\begin{array}{l}\text { YES - } \\
\text { breast }\end{array}$ & - & YES & YES & YES & - \\
\hline 8 & 48 & $\mathrm{~F}$ & $\begin{array}{l}\text { YES - } \\
\text { breast }\end{array}$ & - & YES & - & - & YES \\
\hline 9 & 46 & $\mathrm{~F}$ & $\begin{array}{l}\text { YES - } \\
\text { breast }\end{array}$ & - & YES & - & - & - \\
\hline 10 & 39 & $M$ & $\begin{array}{l}\text { YES - } \\
\text { breast }\end{array}$ & - & YES & - & YES & - \\
\hline 11 & 38 & $F$ & $\begin{array}{l}\text { YES - } \\
\text { pancreatic } \\
\& \text { breast }\end{array}$ & - & YES & - & YES & - \\
\hline 12 & 36 & $\mathrm{~F}$ & $\begin{array}{l}\text { YES - } \\
\text { breast }\end{array}$ & - & YES & YES & - & YES \\
\hline 13 & 34 & $\mathrm{~F}$ & $\begin{array}{l}\text { YES - } \\
\text { breast }\end{array}$ & YES & YES & - & YES & YES \\
\hline 14 & 31 & $M$ & $\begin{array}{l}\text { YES - } \\
\text { breast }\end{array}$ & - & YES & - & - & - \\
\hline 15 & 30 & $M$ & $\begin{array}{l}\text { YES - } \\
\text { breast }\end{array}$ & - & YES & YES & - & YES \\
\hline 16 & 28 & $\mathrm{~F}$ & $\begin{array}{l}\text { YES - } \\
\text { breast }\end{array}$ & - & YES & - & - & - \\
\hline 17 & 24 & $\mathrm{~F}$ & $\begin{array}{l}\text { YES - } \\
\text { breast }\end{array}$ & - & YES & - & - & - \\
\hline
\end{tabular}




\begin{tabular}{|c|c|c|c|c|c|c|c|c|}
\hline $\begin{array}{l}\text { Cases } \\
\#\end{array}$ & $\begin{array}{l}\text { Age at } \\
\text { diagnosis } \\
\text { (years) }\end{array}$ & Gender & $\begin{array}{l}\text { Family } \\
\text { history } \\
\text { with other } \\
\text { types of } \\
\text { cancer }\end{array}$ & $\begin{array}{l}\text { Diagnosed } \\
\text { with colon } \\
\text { cancer }\end{array}$ & $\begin{array}{l}B R C A 1 \text { \& } \\
B R C A 2 \\
\text { mutations }\end{array}$ & $\begin{array}{l}\text { Smoking } \\
\text { history }\end{array}$ & $\begin{array}{l}\text { Chronic } \\
\text { colitis } \\
\text { history }\end{array}$ & $\begin{array}{l}\text { Obesity } \\
\text { (BMI } \geq \\
25 \mathrm{~kg})\end{array}$ \\
\hline 18 & 17 & $\mathrm{~F}$ & $\begin{array}{l}\text { YES - } \\
\text { breast }\end{array}$ & YES & YES & - & YES & YES \\
\hline 19 & 14 & $M$ & $\begin{array}{l}\text { YES - } \\
\text { breast }\end{array}$ & - & YES & - & - & - \\
\hline 20 & 12 & $\mathrm{~F}$ & $\begin{array}{l}\text { YES - } \\
\text { breast }\end{array}$ & - & - & - & - & - \\
\hline 21 & 10 & $\mathrm{~F}$ & $\begin{array}{l}\text { YES - } \\
\text { breast }\end{array}$ & - & YES & - & - & - \\
\hline 22 & 7 & $M$ & $\begin{array}{l}\text { YES - } \\
\text { breast }\end{array}$ & - & YES & - & - & - \\
\hline 23 & 6 & $\mathrm{~F}$ & $\begin{array}{l}\text { YES - } \\
\text { breast }\end{array}$ & - & - & - & - & - \\
\hline 24 & 6 & $\mathrm{~F}$ & $\begin{array}{l}\text { YES - } \\
\text { breast }\end{array}$ & - & - & - & - & - \\
\hline Total & & & $22 / 24$ & $3 / 24$ & $21 / 24$ & $4 / 24$ & $7 / 24$ & $8 / 24$ \\
\hline
\end{tabular}

Table 2

Pathological characteristics (TNM classifications) for the participating consanguineous cases with malignant colon cancer

\begin{tabular}{|ll|}
\hline Stage (TNM Classification) & Number of Patients (\%) \\
\hline T1 - Tumour affects the submucosa $(1-2 \mathrm{~cm})$ & 2 \\
\hline T2 - Tumour affects the muscularis propria $(5 \mathrm{~cm})$ & 1 \\
\hline Total & 3 \\
\hline
\end{tabular}

\section{DNA extraction}

Blood samples were obtained from all the consanguineous cases of affected carriers and patients from a single Saudi family (of four generations). Then, DNA was extracted using the Qiagen DNA Isolation Kit (Cat No./ID: 69506, Quigen, Hilden, Germany), following the manufacturer's instructions. The sample concentration and quality of DNA ratio were assessed using the NanoDrop Spectrophotometer system (Thermo Scientific, USA).

\section{Targeted capture sequencing of BRCA2 / BRCA1 mutations}

Exon coding sequences for the BRCA2 BRCA1 genes were conducted using the heteroduplex analysis, according to the description by [16] or the single-stranded conformation analysis, according to the description 
by [17].

\section{PCR and Sanger sequencing for BRCA2/ BRAC1 mutations detection}

The conventional Sanger sequencing technique was used for the entire $B R C A 2$ and $B R C A 1$ coding sections. The primer three programs were used to design the primers of all the coding exons of $B R C A 2$ and $B R C A 1$ genes. Table 3a shows the primers' sequences for BRCA1. Table $3 \mathrm{~b}$ shows the primers' sequences for BRCA2. The NucleoFast ${ }^{\circledR} 96$ PCR Clean-up Kit purified PCR products, according to the manufacturer's instructions.

The sequencing reactions were conducted using the BigDye ® Terminator v1.1 Cycle Sequencing Kit for every PCR product (purified). The sequencing reaction products were purified using the MontageTM SEQ96 Sequencing Reaction Kit, followed by electrophoresis using the Applied Biosystems 3130 Genetic Analyzer, similar to the previous study [18].

Table 3. BRCA2 and BRCA1 PCR primers

a) BRCA1 primers sequence

\begin{tabular}{|c|c|c|c|}
\hline \multirow[t]{2}{*}{ Exon 2} & Forward & 5'-GAAGTTGTCATTTTATAAACCTTT-3' & 315 \\
\hline & Reverse & 5'-TGTCTTTTCTTCCCTAGTATGT-3' & $\mathrm{bp}$ \\
\hline \multirow[t]{2}{*}{ Exon 5} & Forward & 5'-GCTCTTCGCGTTGAAGAAGT-3' & 400 \\
\hline & Revers e & 5'-GAAGTCTTTTGGCACGGTTT-3' & bp \\
\hline \multirow[t]{2}{*}{ Exon 8} & Forward & 5'-CAGCTTGACACAGGTTTGGA-3' & 499 \\
\hline & Reverse & 5'-TTTCTGGATGCCTCTCAGCT-3' & $\mathrm{bp}$ \\
\hline \multirow[t]{2}{*}{ Exon 11} & Forward & 5'-GAGGACAAAGCAGCGGATAC-3' & 359 \\
\hline & Reverse & 5'- GCTGTAATGAGCTGGCATGA-3' & $\mathrm{bp}$ \\
\hline \multirow[t]{2}{*}{ Exon 18} & Forward & 5'- GGGAGAAGCCAGAATTGACA-3' & 354 \\
\hline & Reverse & 5'- CTCGCTTTGGACCTTGGTG -3' & $\mathrm{bp}$ \\
\hline \multirow[t]{2}{*}{ Exon 23} & Forward & 5'- TTCAGGGGGCTAGAAATCTG-3' & 289 \\
\hline & Reverse & 5'- AAGCTCATTCTTGGGGTCCT -3' & $\mathrm{bp}$ \\
\hline \multirow[t]{2}{*}{ Exon 24} & Forward & 5'- TTCAGGGGGCTAGAAATCTG-3' & 289 \\
\hline & Reverse & 5'- GGGGTATCAGGTAGGTGTCC-3' & $\mathrm{bp}$ \\
\hline
\end{tabular}

b) BRCA2 Primers Sequence 


\begin{tabular}{|c|c|c|c|}
\hline \multirow[t]{2}{*}{ Exon 2} & Forward & 5'- AGCGTGAGGGGACAGATTTG-3' & 519 \\
\hline & Reverse & 5'-GTGGACAGGAAACATCATCTGC -3' & bp \\
\hline \multirow[t]{2}{*}{ Exon 9} & Forward & 5'- AGGAGCTGAGGTGGATCCTG -3' & 980 \\
\hline & Reverse & 5'- TCAGAATTGTCCCAAAAGAGCT -3' & $\mathrm{bp}$ \\
\hline \multirow[t]{2}{*}{ Exon 9} & Forward & 5'- GTTCAGCCCAGTTTGAAGCA -3' & 980 \\
\hline & Reverse & 5'- TGACACTTGGGTTGCTTGTT -3' & $\mathrm{bp}$ \\
\hline \multirow[t]{2}{*}{ Exon 14} & Forward & 5'- TGTCCCGAAAATGAGGAAATGG -3' & 925 \\
\hline & Reverse & 5'- TGTGAAACTGAAAAGACTCTGCA -3' & $\mathrm{bp}$ \\
\hline \multirow[t]{2}{*}{ Exon 18} & Forward & 5'- GGTGGATGGCTCATACCCTC -3' & 809 \\
\hline & Reverse & 5'-TTTGCTGCTTCCTTTTCTTCC-3' & $\mathrm{bp}$ \\
\hline \multirow[t]{2}{*}{ Exon 23} & Forward & 5'- GAAGAATGCAGCAGACCCAG -3' & 751 \\
\hline & Reverse & 5'- TGTCTCTTGAAAGTGGCCCT-3' & op \\
\hline
\end{tabular}

\section{Quantitative genome analysis}

Sequence data was confirmed visually using the snap gene viewer. BRCA2 (accession number: NP_000050.2) and GenBank BRCA1 human sequences (accession number: NP_009225.1) were referenced to the NCBI Reference Sequences Database.

\section{Pedigree analysis}

Factors contributing to colon cancer are carriers of $B R C A 2$ and $B R C A 1$ gene mutations, age-of-onset, tumours type, endogamy and other histories of cancer. Cause and date of death determined the presence of colon cancer for all the descendants of traceable ancestors of the patients. Cancer incidence and pedigree data were registered on a computerised database. The traceable consanguineous cases were patients alive between 2019 and 2020.

\section{Tissue and histological preparation}

Tissue specimens consisted of small biopsies i.e. 7-10 $\mathrm{mm}$ in diameter, obtained from consanguineous cases of the affected patients with colon cancer. Afterwards, tissue specimens underwent transfer to fixation of $10 \%$ buffered formalin. After processing tissue in an automated processor of a 24-hour schedule, blocks of paraffin were sectioned and attained sections of 3-5 $\mu \mathrm{m}$ using conventional histopathology. Moreover, the conventional histopathology applied the Hematoxylin and Eosin (H\&E) technique, as described by [19].

Immunohistochemical stating for BRCA1\&2 
Following the Immunohistochemical expression of BRCA1 and BRCA2 for screening and confirming inherited germline's mutations, BRCA1 \& BRCA2 deficiency is linked to biological mechanisms. Immunohistochemical research was conducted in samples of all the consanguineous cases subjects with paraffin-embedded colon cancer. Sections $5 \mu \mathrm{m}$ tick were obtained from paraffin-embedded wax blocks were put in slides (saline-glass) and later air-dried a night at $37^{\circ} \mathrm{C}$, deparaffinised in xylene, followed by rehydration in some graded alcohol (70 and 100\%). Then, the slides were incubated in 3\% methanol/ $\mathrm{H}_{2} \mathrm{O}_{2}$ for 10 minutes and washed with phosphate-buffered saline (PBS). Primary antibodies, anti-BRCA1 (MS110, mouse monoclonal, 1:200, Abcam, Cambridge, UK), anti-BRCA2 (MAB2476, mouse monoclonal, 1:500; R\&D Systems, Inc. Minneapolis, MN, USA), were used at a diluted ratio of 1:10. Then, the solution was recorded as negative (absent or greatly reduced) of the brown-like nuclear stain, indicating $<20 \%$. However, nuclear staining of $>20 \%$ was regarded as positive (American society of clinical oncology/college of American pathologist clinical practice guideline update, 2013). The sections were subjected to incubation for half a day in the primary antibodies $B R C A 2$ and $B R C A 1$ at $4^{\circ} \mathrm{C}$ and washed with PBS. Consequently, a light microscope was used to examine the immunostaining sections.

\section{Statistical analysis}

The Analytical examinations are performed using the SigmaStat programming adaptation 3.5 (Systat Software, San Jose, CA, USA). Then, the results of the quantitative analysis were expressed in standard deviations and mean. $P$ values $<0.05$ were regarded as statistically significant.

\section{Results}

\section{Deleterious $B R C A 2$ and $B R C A 1$ gene mutations of the participating consanguineous cases}

The age of the consanguineous patients with colon cancer is $17-79$ years. All participants of consanguineous cases inherited both gene mutations. Demetrious BRCA2 and BRCA1 genes were observed in $3 / 24(12.5 \%)$ of consanguineous patients with colon cancer. Contrarily, BRCA genes' mutations were observed in $22 / 24(91.7 \%)$ of consanguineous patients with a family history of breast cancer. Nevertheless, $B R C A$ genes' mutations were recorded in $21 / 24$ (87.5\%) of consanguineous carriers.

In addition, $B R C A$ gene mutations were analysed (Table 4). The $B R C A 1$ gene had 4 mutations in the Kit exon 11 and 2. However, in the BRCA2 gene, two mutations are in the Kit exon 18. Moreover, a substantial amount of $B R C A 1$ gene mutations were the frameshift mutations situated within exon 11 and exon 2.

Overall, the BRCA1 mutations in females and males were $11.06 \%$ and $19.8 \%$, respectively. Nevertheless, the $B R C A 2$ mutation's frequency among females and males was $31.8 \%$ and $48.62 \%$, respectively.

The BRCA genes' mutations frequencies were analysed (Figure 1), and the single-strand conformation analysis (SSCA's) movement in exon 2 (BRCA1) was recorded in consanguineous cases based on 185 del AG mutations, with (15.24\%) in males and (29.16\%) in females. Additionally, SSCA's movement in exon 11 (BRCA1) was recorded for 3279 del C mutations (8.14\%) in males and (12.91\%) in females. Additionally, two 
mutations apply substitution in exon 11 for $2201 \mathrm{C}>\mathrm{T}(20.62 \%)$ in males and $(11.35 \%)$ in females, $2612 \mathrm{C}>\mathrm{T}$ $(9.51 \%)$ in males and $(16.7 \%)$ in females.

On contrary, the sequencing of nucleotides for BRCA2 and BRCA1 showed the absence of frameshift mutations within the BRCA2 gene. However, two substituting mutations in exon 18 indicated novel mutations $139 \mathrm{C}>\mathrm{A}(31.26 \%)$ in males and (45.83\%) in females. Analysed in this study is the substituting mutation for $8415 \mathrm{G}>\mathrm{T}(32.29 \%)$ in males and (51.42\%) in females, which is the common germinal mutation (Figure 1 and Table 4).

Table 4

BRCA2 and BRCA1 inherited mutations for consanguineous cases of four Saudi family's generations

\begin{tabular}{|lllll|}
\hline Gene & Exon & Mutations & Mutation's type & $\begin{array}{l}\text { As reported earlier in other } \\
\text { populations }\end{array}$ \\
\hline BRCA1 & 2 & 185 del AG & Deletion & Yes \\
\cline { 2 - 5 } & 11 & $2201 \mathrm{C}>\mathrm{T}$ & Substitution & Yes \\
\hline 11 & $2612 \mathrm{C}>\mathrm{T}$ & Substitution & Yes \\
\hline BRCA2 & 11 & 3279 del C & Deletion & Yes \\
\cline { 2 - 5 } & $\mathbf{1 3 9} \mathrm{C}>\mathrm{A}$ & Substitution & Yes (reported in our previous study) [15] \\
\hline
\end{tabular}

Only a single Saudi's family met the hereditary non-polyposis colorectal cancer criteria/Lynch syndrome phenotype. Pedigree of the BRCA germline genes' mutations showed 24 consanguineous cases in four generations of the Saudi's family ancestry index case.

From the 24 consanguineous people, 21 consanguineous cases are at the risks of $B R C A$ genes mutations when dealing with extended pedigrees. Blood samples were collected from members of the family to identify the colon cancer incidences and their prior history of breast cancer. Their BRCA2 and BRCA1 were screened with nucleic acids to identify mutations within the proband. For this study, the ratio of relatives was 9 males and 15 females for $B R C A 2$ and $B R C A 1$ genes' mutations carriers (21 out of $24,87.5 \%$ ) and the germline major genetic disorder with $(P=0.00)$. Figure 2 shows the summary of the cancer incidence within the family members. Based on the pedigree analysis, the metachronous tumours comprised of three colon cancers, in which the fourth, third and first generations had a family history of breast and pancreatic cancers. In addition, two cases of breast cancers were recorded. A deceased female was diagnosed with breast cancer. The second case is the breast cancer in the second generation of five affected consanguineous cases with colon and breast cancers in a family.

Figure 2 shows the female patients affected with breast cancer, diagnosed at the age of 53 years based on case \#6 during the second generation. The proband revealed the inherited case of cancer from the father, (in 
which the colon cancer was diagnosed at the age of 79 years, in the first generation). In contrast, a female cousin (had colon cancer diagnosed at the age of 17 years, case \#1 in the fourth generation), having a paternal aunt (who was diagnosed with colon cancer at the age of 34 years, case \#3 in the third generation).

\section{Histopathology}

Histopathological specimens were obtained from colon cancer patients who carried BRCA2 and $B R C A 1$ germline mutations, substantial mitotic numbers and pleomorphism with lesser gland formation instances. In addition, irregular histological formations were noted with high-level tumours grades. A level of proliferation disorganisations was present (Figure $3, b)$, as compared to the normal histological section of the colon (Figure 3, a).

\section{Immunohistochemical stating for BRCA2 and BRCA1}

$B R C A 2$ and $B R C A 1$ expression was examined using immunohistochemistry (Figure 4), revealing strong intensities of staining by $B R C A 1$ and moderate staining by $B R C A 2$ antibodies with tumour tissues of patients with colon cancer. Overexpression of BRCA1 was markedly noted in all the three colons tumours' samples. Nuclear staining, showing over $20 \%$ reactions of positivity with the antibodies, is classified as positive reactions (Figure 4). In addition, the expression of BRCA2 was recorded in all the colon tumours' samples. Moreover, the procedure of antigen retrieval was calculated following the lastly recorded numerical $\mathrm{H}$-scores for every case and obtained by multiplying the scores in respect of the classification as follows: over $50 \%$ (Strong), $20-40 \%$ (moderate), $1-20 \%$ (weak) and 0\% (none).

\section{Discussion}

The history of colorectal cancer is associated with factors that include age-of-onset, $B R C A 2$ and $B R C A 1$ gene mutations, other cancers' history, endogamy, tumours type, cause and date of death. Other associated cofactors are gender, obesity (BMI $\geq 25 \mathrm{~kg}$ ), history of chronic colitis and history of smoking, revealed in all the descendants of the earliest traceable ancestors for patients having colorectal cancer. The main causes and co-factors received consideration in this research in examining the most impactful factors in the inheritance of germline mutations within BRCA2 and BRCA1 genes and the colon cancer incidence in four single family's generations.

The BRCA2 and BRCA1 mutations are regarded as the key factor that increases the colon cancer distribution $[20,21]$ and tumorigenesis of the breast $[15,22,23,26]$ at times of increased cells' division mitotic numbers, a reversal for the distribution of the proliferating cell $[24,25]$.

All the participating family members i.e., consanguineous cases of affected patients and carriers in this research, are inherited of a single novel mutation within the BRCA2 gene (139 C > A) of exon 18, which is the highly common germinal mutation analysed and reported in the prior research [15]. From the findings of both genomes (Figure 1, Table 4) and pedigree (Figure 2), all consanguineous cases showed germline mutations $B R C A 2$ and $B R C A 1$, passed by repeated endogamy of a family with a history of breast and pancreatic cancers, thereby leading to an increase in the risk of colon cancer $[15,18,20]$, pancreatic $[20,21]$ and breast cancer $[15,22,23]$. However, one female family member showed germline mutations within BRCA2 and 
$B R C A 1$ and married an unrelative male with no such mutations. They have twin daughters with no germline mutations of BRCA2 and BRCA1.

In addition, colon tissues' immunohistochemical data indicated overexpression of $B R C A 1$ while it positively stained the BRCA2. These findings were consistent with previous studies [27, 28], showing a substantial relationship between expressions of $B R C A 1 / 2$ and the advanced stage of the tumour as indicated in (Figure 3 , $b$ and $a)$.

In this current research, variables that increased colon cancer's incidence rates are age, gender, history of chronic colitis, obesity (BMI $\geq 25 \mathrm{~kg}$ ) and smoking history.

For gender, Wang et al., (2020) showed that it was imperative to incorporate gender as a major factor when diagnosing and treating colon cancer. Sex-specific tools of colon cancer's diagnoses in women help in developing ways of increasing the chemotherapy rate in women $[26,29]$.

In contrast, the age factor plays a crucial role in colon cancer incidences. Several studies have shown the importance of healthy lifestyles in reducing colon cancer for the teenage group [26]. This present study revealed a similar impact of healthy lifestyles on two associated factors such as obesity 8/24 (33.33\%) and history of chronic colitis 7/24 (29.16\%) [30]. Many studies confirmed that unhealthy foods with hot spices, fast foods with unhealthy nutritional values and meals without fresh fruits and vegetables could increase the incidences of obesity and chronic colitis, particularly when there was a family cancer history [31 - 33]. These issues could increase breast and colon cancers incidences at a younger age [26].

As shown in Table 4, the smoking history was recorded as 4/24(16.7\%). However, none of the smokers had colon cancer. Nonetheless, smoking history was used in this study in assessing all the potential cofactors that could increase breast and colon cancer incidence within a single-family as previously reported [31, 33].

\section{Conclusion}

This study proposes that highly germline mutations through inheritance of $B R C A 2$ and $B R C A 1$ and increase of breast and colon cancer over the four generations were associated with the repeated endogamy between consanguineous cases who carried germinal mutations of BRCA2 and BRCA1. Nevertheless, other factors such as a history of chronic colitis and obesity could result in early-onset of colon cancer for young people as indicated in the consanguineous cases in the family's fourth generation.

\section{Abbreviations}

\section{A}

Adenine (1 of 4 bases found in a DNA molecule)

BRCA1

Human gene stand for breast cancer 1 as reported by the HUGO Gene Nomenclature Committee BRCA2

Human gene stand for breast cancer 2 as reported by the HUGO Gene Nomenclature Committee C

Page $11 / 18$ 
Cytosine ( 1 of 4 bases found in a DNA molecule)

CC

Colon cancer

del

Deletion

\section{DNA}

Deoxyribonucleic acid OR a double-stranded RNA molecule

dx

The age at diagnosis

IHC

Immunohistochemistry

$\mathrm{mm}$

Millimeter

$\mu \mathrm{m}$

Micrometer

PBS

Phosphate buffered saline

SGV

Snap gene viewer

\section{SSCA}

Single-strand conformation analyses

$\mathrm{T}$

Thymine (1 of 4 bases found in a DNA molecule)

\section{Declarations}

\section{Ethics approval and consent to participate}

Written informed consent for participation were obtained from all the participants. Each participant \& the patients' parents (under the age of 18) agreed to participate in the present study. The study was approved by written letter from King Fahad Medical City according to ICH GCP H-01-R059 guidelines, IRB LOG number 200287, dated on August 27, 2020.

\section{Consent for publication}

Written informed consent for publication were obtained from all the participants. Each participant \& the patients' parents (under the age of 18) agreed to publish their clinical details, identifying images, genetic analyses \& other personal details.

\section{Availability of data and material}

All relevant data are presented within the paper.

\section{Competing interests}


The authors declare that they have no competing interests.

\section{Funding}

This research was funded by the Deanship of Scientific Research at Princess Nourah Bint Abdulrahman University through the Fast-track Research Funding Program. The funder had no role in the study design, data collection and analysis, decision to publish, and manuscript preparation.

\section{Authors' Contributions}

'DA' Participated in formal analysis, performed experimental works, investigation, methodology, resources, review, and editing; 'TA' Participated in conceptualization, formal analysis, investigation, methodology, review, and editing; 'MA' Participated in performed experimental works, data curation, methodology, resources, review, and editing; 'DD' Participated in methodology, resources, funding acquisition, review, and editing; 'AAA' Participated in formal analysis, methodology, software; 'FA' Participated in performed experimental works, Data curation, Methodology, Resources, review, and editing; 'GA' Participated in performed experimental works, investigation, methodology, resources, review, and editing; 'WA' Project administration, formal analysis, investigation, wrote the original draft and submitted the paper as a corresponding author. All authors read and approved the final manuscript.

\section{Acknowledgements}

Not applicable.

\section{References}

1. Wang D, DuBois RN. The role of anti-inflammatory drugs in colon cancer. Annual review of medicine. 2013 Jan;14;64:131-44.

2. Maccaroni E, Giampieri R, Lenci E, Scortichini L, Bianchi F, Belvederesi L, Brugiati C, Pagliaretta S, Ambrosini E, Berardi R. BRCA mutations and gastrointestinal cancers: When to expect the unexpected? World Journal of Clinical Oncology. 2021 Jul;24(7):565. 12(.

3. Yang $\mathrm{H}$, Shi L, Wang Y, Duan G, Wang Y. RE: BRCA1 and BRCA2 Gene Mutations and Colon Cancer Risk: Systematic Review and Meta-Analysis. JNCl: Journal of the National Cancer Institute. $2020 \mathrm{Apr}$ 1;112(4):426-7.

4. Katona BW, Stadler ZK, Robson ME, Domchek SM. RE: BRCA1 and BRCA2 Gene Mutations and Colon Cancer Risk: Systematic Review and Meta-analysis. JNCl: Journal of the National Cancer Institute. 2019 May 1;111(5):522-3.

5. Larsen MJ, Thomassen M, Gerdes AM, Kruse TA. Hereditary breast cancer: clinical, pathological and molecular characteristics. Breast cancer: basic and clinical research. 2014 Jan;8: BCBCR-S18715.

6. Kupfer SS, Gupta S, Weitzel JN, Samadder J. AGA Clinical Practice Update on Colorectal and Pancreatic Cancer Risk and Screening in BRCA1 and BRCA2 Carriers: Commentary. Gastroenterology. 2020 Aug 1;159(2):760-4. 
7. Laish I, Friedman E, Levi-Reznick G, Kedar I, Katz L, Levi Z, Halpern N, Parnasa S, Abu-Shatya A, Half E, Goldberg Y. Double heterozygotes of BRCA1/BRCA2 and mismatch repair gene pathogenic variants: case series and clinical implications. Breast Cancer Res Treat. 2021 Jun;4:1-0.

8. Cullinane CM, Creavin B, O'Connell EP, Kelly L, O'Sullivan MJ, Corrigan MA, Redmond HP. Risk of colorectal cancer associated with BRCA1 and/or BRCA2 mutation carriers: systematic review and metaanalysis. Journal of British Surgery. 2020 Jul;107(8):951-9.

9. Ediriweera DS, Kasturiratne A, Pathmeswaran A, Gunawardena NK, Wijayawickrama BA, Jayamanne SF, Isbister GK, Dawson A, Giorgi E, Diggle PJ, Lalloo DG. Mapping the risk of snakebite in Sri Lanka-a national survey with geospatial analysis. PLoS neglected tropical diseases. 2016 Jul 8;10(7): e0004813.

10. Kumar D, Panigrahi MK, Suryavanshi M, Mehta A, Saikia KK. Quantification of DNA extracted from formalin fixed paraffin-embeded tissue comparison of three techniques: Effect on PCR efficiency. Journal of Clinical Diagnostic Research: JCDR. 2016 Sep;10(9):BC01.

11. Alcaide M, Cheung M, Bushell K, Arthur SE, Wong HL, Karasinska J, Renouf D, Schaeffer DF, McNamara S, du Tertre MC, Batist G. A novel multiplex droplet digital PCR assay to identify and quantify KRAS mutations in clinical specimens. The Journal of Molecular Diagnostics. 2019 Mar 1;21(2):214-27.

12. Nataraj AJ, Olivos-Glander I, Kusukawa N, Highsmith WE Jr. Single-strand conformation polymorphism and heteroduplex analysis for gel-based mutation detection. ELECTROPHORESIS: An International Journal. 1999 Jan 1;20(6):1177-85.

13. Bancroft JD, Gamble M, editors. Theory and practice of histological techniques. Elsevier health sciences; 2008.

14. Al-Qahtani WS, Al-Olayan E, Albani FG, Suliman RS, Aljarba NH, Al-Humaidhi EM, Almurshedi AS, Domiaty DM, Alduwish MA, Al-Otaibi AM, Elasbali AM. Utility of KRAS Gene and Clinicopathological Features in the Assessment of the Risk of Type 2 Diabetes in the Etiology of Colon Cancer. Global Medical Genetics. 2020 Aug 31.

15. Algebaly AS, Suliman RS, Al-Qahtani WS. Comprehensive study for BRCA1 and BRCA2 entire coding regions in breast cancer. Clinical \& Translational Oncology. Official Publication of the Federation of Spanish Oncology Societies and of the National Cancer Institute of Mexico; 2020 May. p. 25.

16. Lancaster JM, Wooster R, Mangion J, Phelan CM, Cochran C, Gumbs C, Seal S, Barfoot R, Collins N, Bignell G, Patel S. BRCA2 mutations in primary breast and ovarian cancers. Nat Genet. 1996 Jun;13(2):238-40.

17. Apessos A, Agiannitopoulos K, Pepe G, Tsaousis GN, Papadopoulou E, Metaxa-Mariatou V, Tsirigoti A, Efstathiadou C, Markopoulos C, Xepapadakis G, Venizelos V. Comprehensive BRCA mutation analysis in the Greek population. Experience from a single clinical diagnostic center. Cancer Genetics. 2018 Jan;1:220:1-2.

18. Suliman, et al. " Role of Human PTEN and TP53 Sequence Mutations in the Etiology of Breast Cancer in Saudi Patients. Pakistan Journal of Biological Sciences. 2020 May 321-330.

19. Tian H, Brody LC, Landers JP. Rapid detection of deletion, insertion, and substitution mutations via heteroduplex analysis using capillary-and microchip-based electrophoresis. Genome Research. 2000 Sep 1;10(9):1403-13. 
20. Levy-Lahad E, Friedman E. Cancer risks among BRCA1 and BRCA2 mutation carriers. British journal of cancer. 2007 Jan;96(1):11-5.

21. Cicenas J, Kvederaviciute K, Meskinyte I, Meskinyte-Kausiliene E, Skeberdyte A. KRAS, TP53, CDKN2A, SMAD4, BRCA1, and BRCA2 mutations in pancreatic cancer. Cancers. 2017 May;9(5):42.

22. Mehrgou A, Akouchekian M. The importance of BRCA1 and BRCA2 genes mutations in breast cancer development. Medical journal of the Islamic Republic of Iran. 2016;30:369.

23. Venkitaraman AR. How do mutations affecting the breast cancer genes BRCA1 and BRCA2 cause cancer susceptibility? DNA Repair. 2019 Sep;1;81:102668.

24. Sarkar S, Sahoo PK, Mahata S, Pal R, Ghosh D, Mistry T, Ghosh S, Bera T, Nasare VD. Mitotic checkpoint defects: en route to cancer and drug resistance. Chromosome Res. 2021 Jan;6:1-4.

25. Van Gijn SE, Wierenga E, van den Tempel N, Kok YP, Heijink AM, Spierings DC, Foijer F, van Vugt MA, Fehrmann RS. TPX2/Aurora kinase A signaling as a potential therapeutic target in genomically unstable cancer cells. Oncogene. 2019 Feb;38(6):852-67.

26. Russo AG, Andreano A, Sartore-Bianchi A, Mauri G, Decarli A, Siena S. Increased incidence of colon cancer among individuals younger than 50 years: A 17 years analysis from the cancer registry of the municipality of Milan, Italy. Cancer epidemiology. 2019 Jun 1;60: 134-40.

27. Kim HS, Kim JW, Hwang IG, Lee HS, Kim WH. Expression of DNA Damage Response Markers in EarlyOnset or Familial Gastric Cancers. Asian Pacific journal of cancer prevention: APJCP. 2019;20(5):1369.

28. Hussein IA, Ahmed ST, Hameedi AD, Naji RZ, Alharbawi L, Alkhaytt M, Pity IS. Immunohistochemical. Expression of BRCA1 Protein, ER, PR and Her2/neu in Breast Cancer: A Clinicopathological Study. Asian Pacific Journal of Cancer Prevention. 2020 Apr 1;21(4):1025-9.

29. Bonyan AS, Bonyan SS, Hussain AG. Assessment of immunohistochemical Expression of HER2\Neu and BRCA1 in Colorectal Tumors and it's Correlation with Clinicopathological Variables. University of Thi-Qar Journal Of Medicine. 2020 Sep 7;19(1):92-105.

30. Lo CH, Lochhead P, Khalili H, Song M, Tabung FK, Burke KE, Richter JM, Giovannucci EL, Chan AT, Ananthakrishnan AN. Dietary Inflammatory Potential and Risk of Crohn's Disease and Ulcerative Colitis. Gastroenterology. 2020 May 7.

31. Nadeem MS, Kumar V, Al-Abbasi FA, Kamal MA, Anwar F. Risk of colorectal cancer in inflammatory bowel diseases. InSeminars in cancer biology 2020 Aug 1 (Vol. 64, pp. 51-60). Academic Press.

32. Damas OM, Abreu MT. Are patients with ulcerative colitis still at increased risk of colon cancer?. The Lancet. 2020 Jan 11;395(10218):92-4.

33. Li L, Weiss HL, Li J, Chen Z, Donato L, Evers BM. High plasma levels of pro-NT are associated with increased colon cancer risk. Endocrine-Related Cancer. 2020 Nov 1;27(11):641-6.

\section{Figures}


Male

- Female

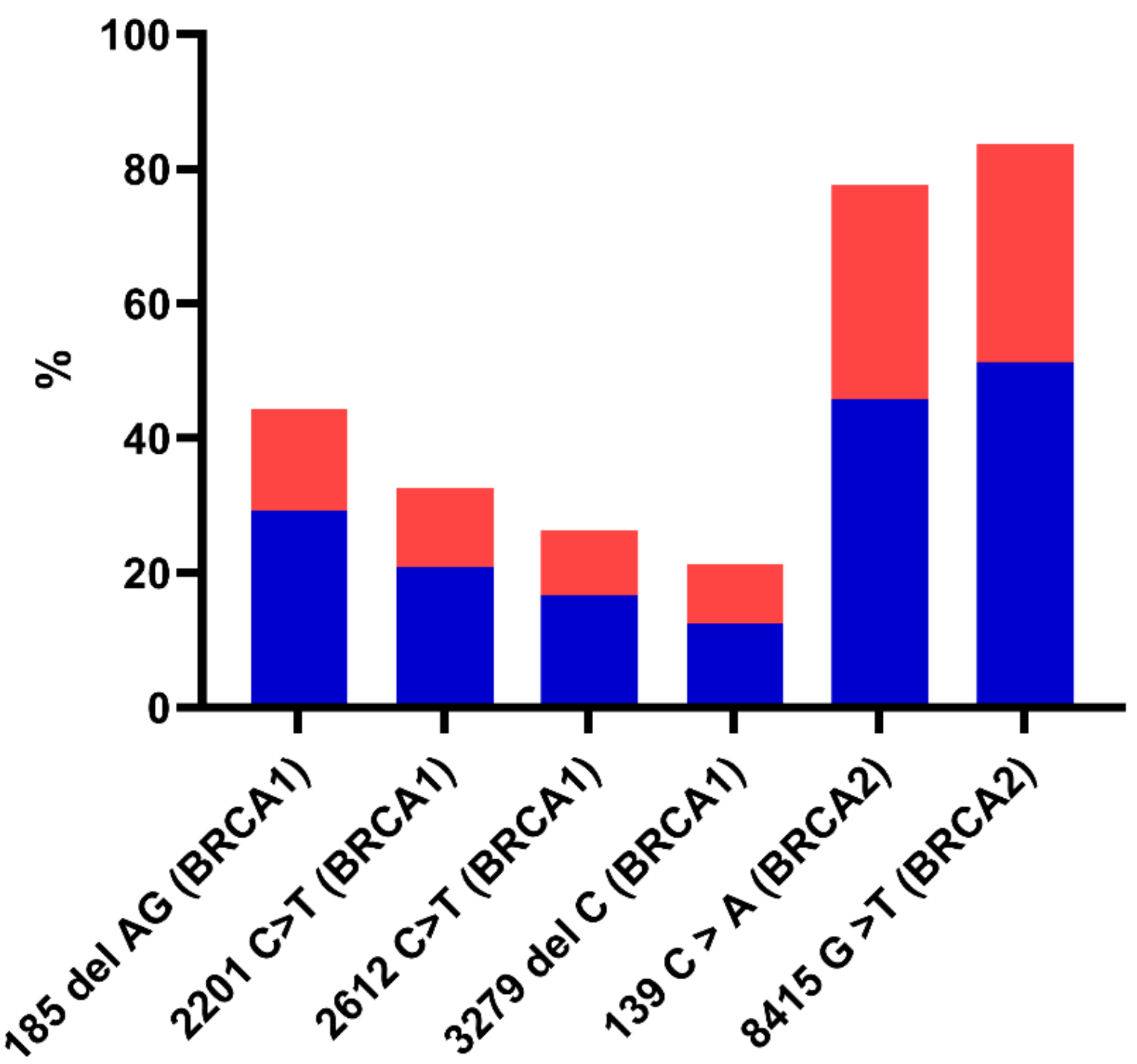

Figure 1

Inherited mutations in BRCA2 and BRCA1 genes' frequencies for consanguineous cases in four generations of a Saudi family 


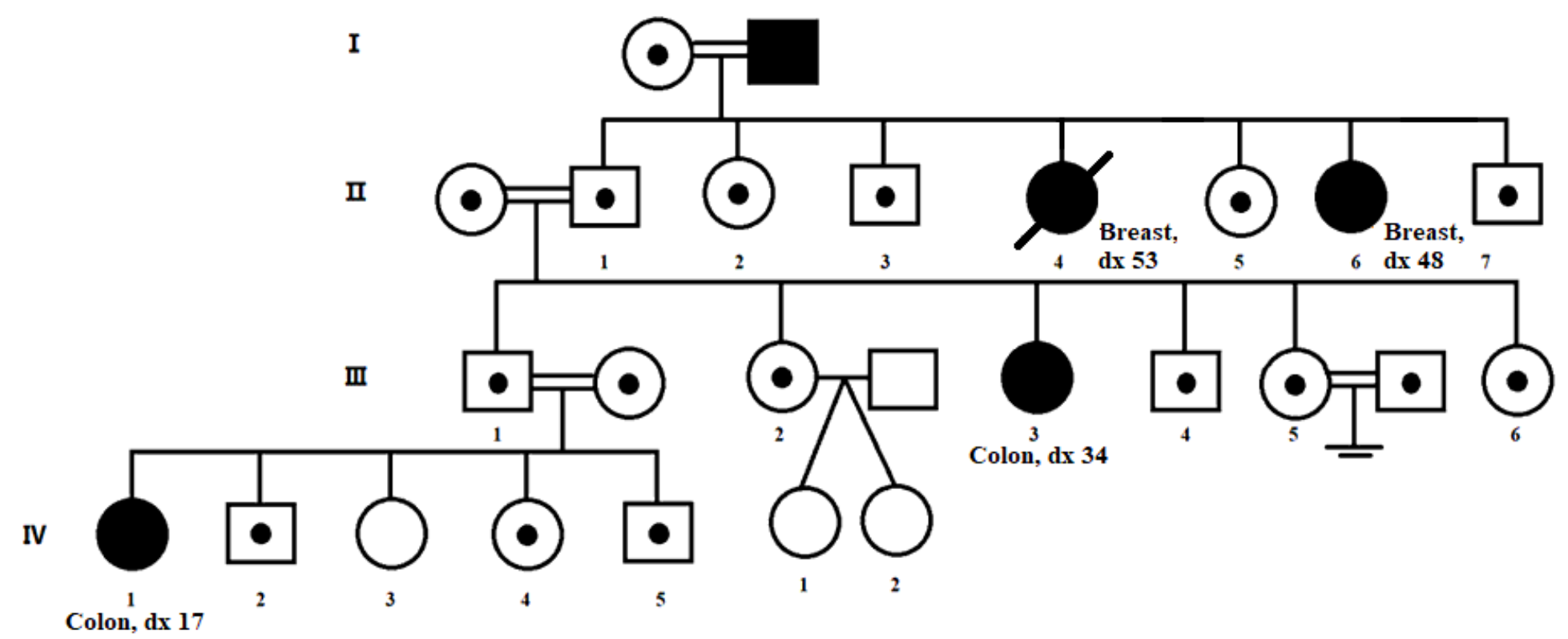

Figure 2

Pedigree indicating inherited characteristics of a family having deleterious BRCA2 and BRCA1 mutations through four generations, entailing transmission of breast and colon cancers due to paternal and maternal lineages.
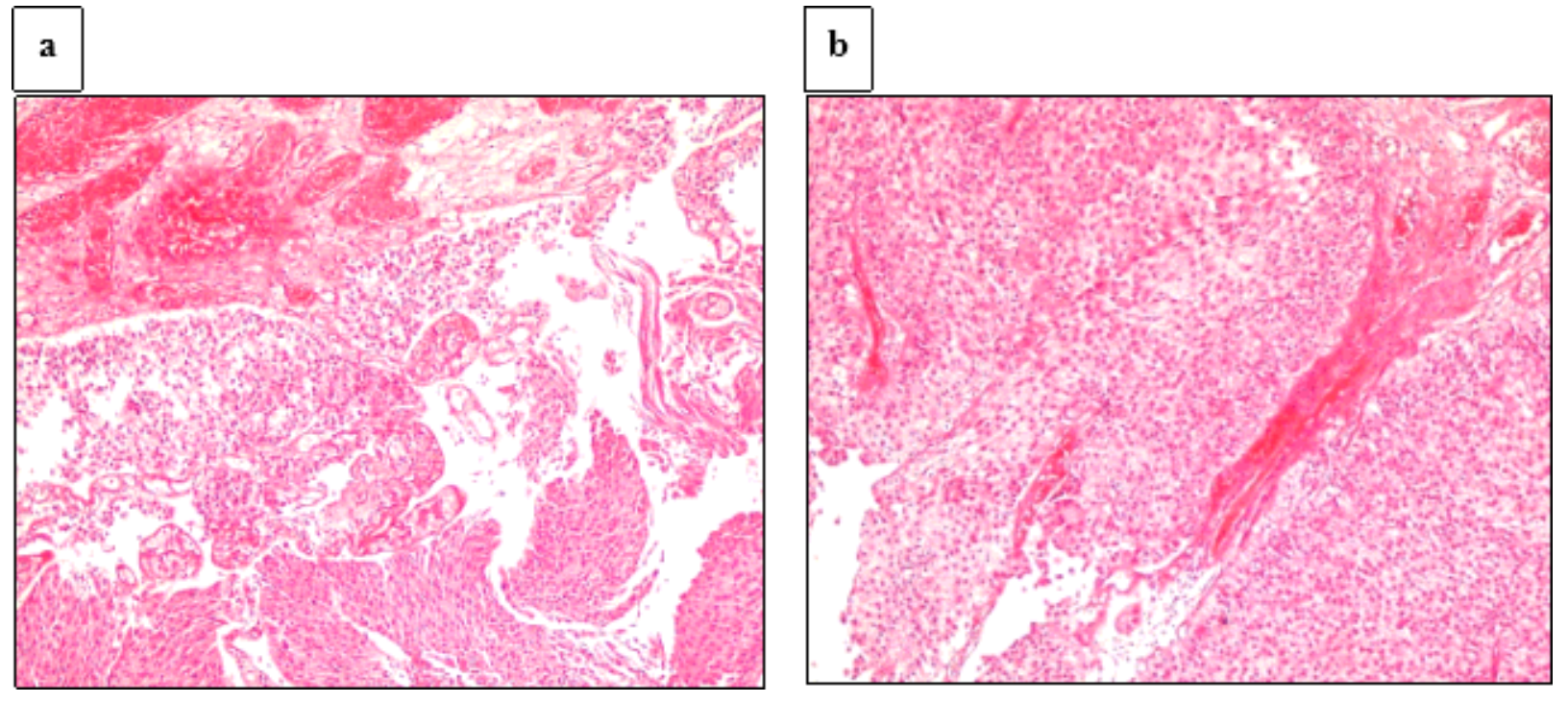

\section{Figure 3}

Photomicrographs for H\&E section (stained) with the colon cancer of the relative patients using scale bar $(100 \mu \mathrm{m})$ with section stained from a patient with colon cancer of BRCA2's mutations within exon 18 and BRCA1's mutations and within exon 2 (a) exon 11. However, BRCA2 mutations are in exon 18 (b). In addition, views of sections of colon cancer are noted with amplified cell activity (mitotic), variable pleomorphism grades, proliferation dysregulation, no formation of the gland, necrosis and cell pleomorphism (nuclear) with patterns of asymmetry for colon cells, as well as production of mucin and full of red blood cells. 


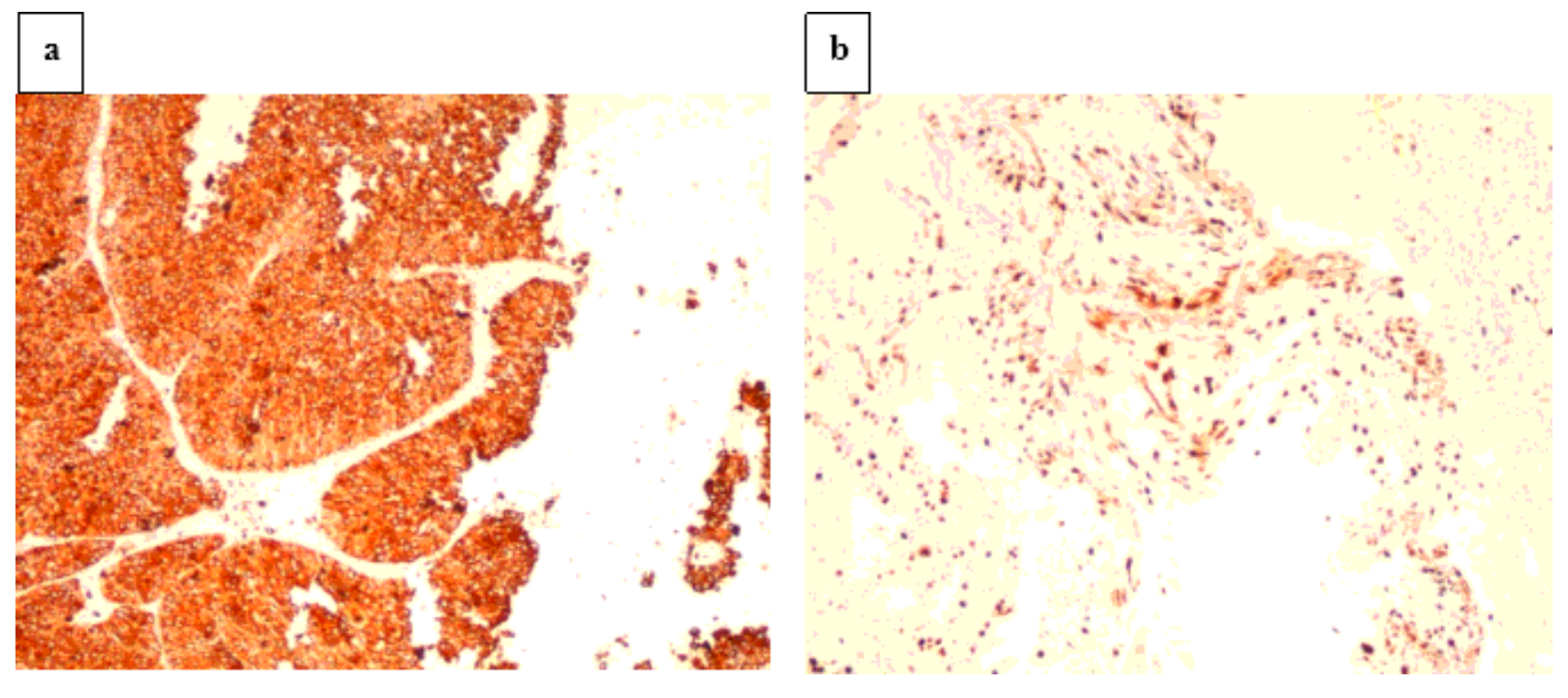

\section{Figure 4}

Immunostained sections' photomicrographs from patients with colon cancer, with BRCA2 and BRCA1 antibodies, were obtained by a light microscope using a scale bar: $100 \mu \mathrm{m}$. Immunohistochemical slide for staining with BRCA1's mutants showed BRCA1 protein's overexpression in tissue from the patient of colon cancer diagnosed with the T2 - Tumour that affected the muscularis propria (a). The slide stained using BRCA2 antibody revealed positive staining within BRCA2 mutants' patient of colon cancer tissue and diagnosed as having T1 - Tumor that affected the submucosa (b). 